\title{
Zinc Tempers Haloperidol-induced Behavioural Changes in Healthy Mice
}

\author{
Onaolapo OJ ${ }^{1}$, Ayanwale $\mathrm{T}^{2}$, Agoi $\mathrm{O}^{2}$, Adetimehin $\mathrm{C}^{2}$, Onaolapo AY.,* \\ ${ }^{1}$ Department of Pharmacology and Therapeutics, Faculty of Basic Medical Sciences, College of Health Sciences, \\ Ladoke Akintola University of Technology, Nigeria \\ ${ }^{2}$ Department of Anatomy, Faculty of Basic Medical Sciences, College of Health Sciences, \\ Ladoke Akintola University of Technology, Nigeria
}

Copyright $(2016$ by authors, all rights reserved. Authors agree that this article remains permanently open access under the terms of the Creative Commons Attribution License 4.0 International License

\begin{abstract}
Objective: Behavioural changes secondary to haloperidol/zinc administration were studied, with a view to understanding the patterns of behavioural responses that may be exhibited after such treatment in healthy mice. Methodology: 6 month old Swiss mice (24-30 g each, $n=12$ ), were given vehicle (distilled water), haloperidol $(2 \mathrm{mg} / \mathrm{kg}$ ), zinc (as Zinc gluconate, 2.5 and $5 \mathrm{mg} / \mathrm{kg}$ ) or haloperidol/zinc combination, orally for 21 days. Behaviours were assessed after the first and last dose of haloperidol/zinc. Results: Zinc administration led to a significant reduction of haloperidol-induced suppression of horizontal locomotion, rearing and grooming behaviours. $\mathrm{Zn}$ also prevented the deterioration in Y-maze and radial-arm maze working-memory that was associated with repeated haloperidol administration. Finally, an enhanced anxiolytic effect was seen with co-administration of haloperidol with the lower dose of zinc. Conclusion: Co-administration of haloperidol with zinc can reduce some unwanted effects that are known to be associated with haloperidol therapy; hence zinc may be a beneficial adjunct to haloperidol administration.
\end{abstract}

Keywords Antipsychotic, Neurobehaviour, Supplement, Trace Element, Memory, Novelty-induced Behaviour, Anxiety

\section{Introduction}

Antipsychotic medications are increasingly being used in the management of mental disorders. Their use ranges from treatment of schizophrenia to the management of behavioural symptoms that may occur with certain types of dementia. Haloperidol is a 'typical' antipsychotic drug used in the treatment of adult schizophrenia and mania, and hyperactivity/behavioural disorders in children [1]. It binds with high affinity to dopamine ${ }_{2}\left(\mathrm{D}_{2}\right.$ receptor), but also has affinity for the $\mathrm{D}_{3}$ and $\mathrm{D}_{4}$ dopamine receptors [2]. Its effect on locomotion is mediated by its blockade of central dopaminergic receptors [3]. Haloperidol's blockade of $\mathrm{D}_{2}$ receptors in the brain is also responsible for its effect on cognition [4] and reinforcement behaviours [5]. Administration of haloperidol results in suppression of voluntary behaviours such as motor activity; this is one of the most prominent observable effects of antipsychotics [6,7]. In experimental animals, it has central-inhibiting effects, causing a decrease in both horizontal and vertical locomotion [8]. Unfortunately, haloperidol causes deficits in learning and memory in both humans and experimental animals $[9,10,11]$, an observation that had been made even in healthy volunteers; supporting the fact that haloperidol alters behaviour even in the non mentally-ill $[12,13]$. In humans, other adverse reactions that may follow haloperidol administration include drowsiness, lethargy, drooling or hypersalivation and a fixed stare.

The side-effects that may be associated with drugs such as haloperidol constitute major impediments to therapy, and a significant reduction in their occurrence is always desirable; due to the fact that serious side-effects discourage regular and continued use of drugs [14]. Therefore, modulation of some unwanted effects of haloperidol is a desired end-point.

In recent times, there has been a great deal of interest in the use of natural remedies, multivitamins or trace element supplements, either in the direct treatment of mental-health disorders or to help reduce the quantity of medications required for treatment. A number of studies have also reported a strong correlation between nutritional deficiencies [14], mineral excess/deficiencies [15] and mental illnesses [16]. The most common nutritional deficiencies seen in mental disorder patients are of omega-3 fatty [17] and B vitamins [18], while overload or deficiency of essential trace elements like zinc, selenium, copper, manganese [19] and iron have also been implicated.

Zinc $(\mathrm{Zn})$ is an essential mineral, which is found naturally in some foods, and is available as a dietary supplement. It 
plays a key role in protein synthesis, DNA synthesis, cell division and immune function [20]; it is also an important micronutrient which helps in normal growth and development [21]. $\mathrm{Zn}$ is vital to the catalytic activity of over a hundred enzymes [22,23], apart from being an integral part of the structure of main antioxidant enzymes like superoxide dismutase [24]. A daily intake of $\mathrm{Zn}$ is recommended to maintain a steady state in the body. $\mathrm{Zn}$ is also one of the micronutrients that have been linked to behaviour, learning, memory and mental-health disorders such as schizophrenia and depression [25]. Studies have reported alterations in the copper/zinc ratio in patients with schizophrenia [26]. A number of researchers also believe that $\mathrm{Zn}$ is probably a neurotransmitter; an opinion buttressed by the observations that $\mathrm{Zn}$ is found in high concentrations in certain regions of the brain, such as the hippocampus, and that $\mathrm{Zn}$ deficiency can produce behaviours that are similar to those found in schizophrenics [27]. Zn supplementation in this study was in the form of zinc gluconate caplets which contains approximately $13 \%$ zinc by weight. We administered 2.5 and $5.0 \mathrm{mg} / \mathrm{kg}$ of zinc gluconate which is approximately 0.325 and $0.65 \mathrm{mg} / \mathrm{kg}$ of elemental zinc daily. The doses used in this study correspond to about 21 and $42 \mathrm{mg}$ in a young adult human weighing about $60 \mathrm{~kg}$. These doses, though higher than the recommended daily allowance of $8-11 \mathrm{mg} / \mathrm{kg}$ in adults are within and slightly above the upper daily limit of $40 \mathrm{mg}$ in adults 19 years and above [23]. There have been reports of increased risk of adverse health effects with long-term $\mathrm{Zn}$ intake exceeding the tolerable upper limit [23]. These 'upper limits' however do not usually apply to individuals receiving $\mathrm{Zn}$ for medical treatment under the care of a physician, i.e. when $\mathrm{Zn}$ is being used as a therapeutic agent [28].

The rationale for this study is that if $\mathrm{Zn}$ is likely to become an adjunct agent in the management of certain mental illnesses (where there is $\mathrm{Zn}$ deficit), it will be of benefit for us to be familiar with the baseline behavioural effects of $\mathrm{Zn} /$ standard antipsychotic in health. We therefore tested the hypothesis that co-administration of $\mathrm{Zn}$ with haloperidol can lead to a significant alteration of the behavioural effects of haloperidol in healthy mice.

\section{Materials and Methods}

\subsection{Equipment and Apparatus}

Open-field, Y-maze, Radial-arm maze, Elevated plus-maze.

\subsection{Dietary Supplements}

Zinc gluconate Caplets (each caplet contained $6.5 \mathrm{mg}$ of elemental $\mathrm{Zn}$ ), Haloperidol tablets.

\subsection{Animals}

6 month old Swiss mice from our colony (Empire Breeders, Osogbo, Osun State, Nigeria), weighing 24-30 g each were used for this study. Mice were housed in groups of six in plastic cages located in a temperature-controlled quarters (22-25 degree Celsius) with 12 hour light/dark cycle. All animals were fed commercial standard chow (Calories: $29 \%$ Protein, $13 \%$ Fat and 58\% Carbohydrate) from weaning. Mice had free access to food and drinking water except during the behavioural tests. All procedures were conducted in accordance with the approved institutional protocols and within the provisions for animal care and use prescribed in the scientific procedures on living animals, European Council Directive (EU2010/63).

\subsection{Experimental Method}

Two hundred and forty healthy mice of either sex were randomly assigned into three main groups, based on the behavioural tests carried out on them: Open field (72), working-memory (84) and anxiety tests (84). They were further divided into 6 groups of 12 animals each, for the open field test and 7 groups of 12 animals each, for the cognition and anxiety tests respectively. Animals in each group received vehicle (distilled water) at $10 \mathrm{ml} / \mathrm{kg}$, haloperidol (2 $\mathrm{mg} / \mathrm{kg}$ ) [29], Zn (as 2.5 or $5.0 \mathrm{mg} / \mathrm{kg} / \mathrm{day}$ of zinc gluconate, administered alone or co administered with haloperidol), or a standard drug (diazepam at $0.5 \mathrm{mg} / \mathrm{kg}$ for the anxiety test and scopolamine at $1 \mathrm{mg} / \mathrm{kg}$ for cognition test) daily for 21 days, via an oral cannula. All animals were gavaged daily starting at $9.00 \mathrm{a} . \mathrm{m}$; gavage was used as method of drug delivery to simulate administration in humans. Route of administration of drug or vehicle was oral. Doses of $\mathrm{Zn}$ and haloperidol were calculated by crushing the tablets and dissolving measured quantities in distilled water. Behavioural tests were carried out after the first (acute) and last (repeated) dose of vehicle or drug.

\subsubsection{Behavioural Testing}

Behavioural tests were carried out in a quiet room between the hours of 9 a.m. and 2 p.m. On each of the test days, animals were transported to the testing room in their home cages, and allowed to acclimatize for 30 minutes before behavioural tests. At the onset of the tests, each animal was placed in the apparatus and its behaviour videotaped for subsequent analysis. After testing, each mouse was removed from the maze, and returned to its home cage. The maze is cleaned thoroughly with $70 \%$ ethanol and then wiped dry to remove any trace of odour.

\subsubsection{Open Field}

Open field novelty-induced behaviours such as horizontal locomotion, rearing and grooming were recorded over a twenty minute period [30]. The open field box is a rectangular arena made up of a hard floor measuring $36 \times 36$ x $26 \mathrm{~cm}$, its floor was divided into 16 equal squares. The mice were placed in the centre of the field and covered by a small dome which was removed at the beginning of video 
recording of their activity. After administration of vehicle or drug, mice were introduced into the field and the total horizontal locomotion (number of floor units entered with all paws), rearing frequency (number of times the animal stood on its hind legs either with its fore arms against the walls of the observation cage or free in the air) and frequency of grooming (number of body cleaning with paws, picking of the body and pubis with the mouth and face washing actions, indicative of a stereotypic behaviour) within the 20 minute interval was recorded.

\subsubsection{Memory (Y-maze, Radial arm-maze)}

Y-maze was used to measure spontaneous alternation, a measure of working-memory. Spontaneous alternation was assessed using a Y-shaped maze which was composed of three equally spaced arms $\left(120^{\circ}, 41 \mathrm{~cm}\right.$ long and $15 \mathrm{~cm}$ high, $5 \mathrm{~cm}$ wide). Each mouse was placed in one of the arm compartments and allowed to move freely until its tail completely entered another arm. The sequence of arm entries was recorded. An alternation was defined as entry into all three arms consecutively [31]. The number of actual alternations is number of sequential arm entries into three arms, designated $\mathrm{A}, \mathrm{B}$ and $\mathrm{C}$. The percentage alternation is calculated as $\{$ (Actual alternations/Total arm entry minus two) $\mathrm{x} 100\}$ in a 5 minute interval.

Working-memory in the radial-arm maze was measured as alternation index, which is the ratio of sequential arm entries before error and total arm entry. The apparatus is made up of eight equidistantly spaced arms, each about $33 \mathrm{~cm}$ long, all radiating from a small circular central platform. Working-memory was assessed when the rat enters each arm a single time. Re-entry into the arms would result in a working-memory error [31].

\subsubsection{Anxiety Model: Elevated plus-maze (EPM)}

The EPM validated for use in mice, relies upon the rodents' proclivity toward dark, enclosed spaces (approach) and an unconditioned fear of heights/open spaces (avoidance). It is plus-shaped, with two open arms measuring $25 \times 5 \times 5 \mathrm{~cm}$ lying across from each other and perpendicular to two closed arms measuring $25 \times 5 \times 16 \mathrm{~cm}$ with a centre platform $(5 \times 5 \times 0.5 \mathrm{~cm})$. The closed arms are enclosed by 2 high walls $(16 \mathrm{~cm})$ while the open arms have no side wall. Animals are placed in the central platform facing the closed arm and behaviours recorded for 5 minutes. The criterion for arm visit is considered only when the animal decisively moved all its four limbs into an arm [32].

\subsection{Statistical Analysis}

Data was analysed using Chris Rorden's ezANOVA for windows. Hypothesis was tested using analysis of variance (ANOVA). We tested the hypothesis that acute or repeated oral co-administration of $\mathrm{Zn} /$ haloperidol could significantly alter haloperidol-induced behaviours in healthy mice. Two-factor ANOVA was used to test effects of $\mathrm{Zn}$ and haloperidol co-administration and duration of administration (acute versus repeated) on behaviour, while one-way ANOVA was used to assess the effects of $\mathrm{Zn}$ and haloperidol administration on body weight. Tukey (HSD) test was used for within and between group comparisons. Results were expressed as mean \pm S.E.M, and $p<0.05$ considered significant.

\section{Results}

\subsection{Effect of $\mathbf{Z n} / \mathbf{h a l o p e r i d o l ~ A d m i n i s t r a t i o n ~ o n ~ B o d y ~}$ Weight}

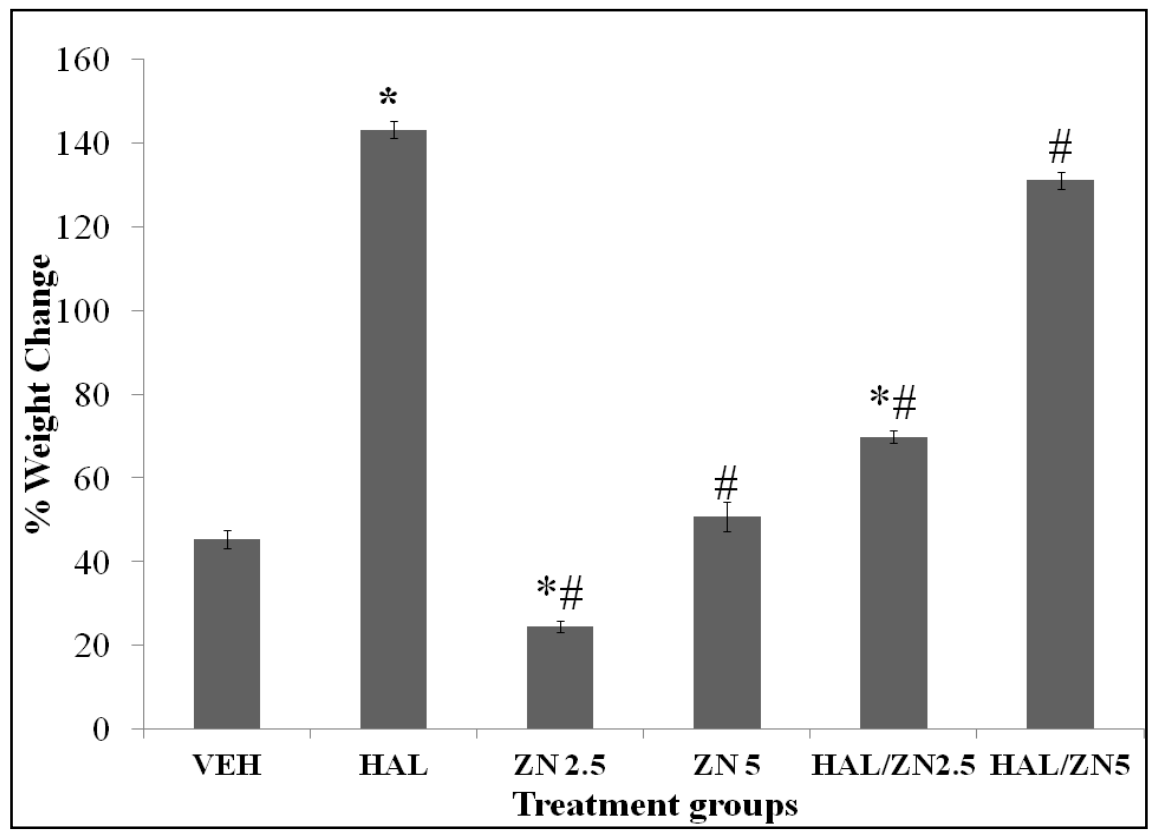

Figure 1. Effect of $\mathrm{Zn} /$ haloperidol administration on body weight. Each bar represents mean \pm S.E.M, number of mice per treatment group $=12$; VEH: Vehicle, HAL: Haloperidol, ZN: Zinc, HAL/ZN: Haloperidol Zinc co-administration. 
Figure 1 represents the percentage weight change, defined as the percentage difference between the final and initial body weights divided by initial weight. There was a significant $(\mathrm{F}=29.41 \mathrm{p}<0.001)$ increase in weight in groups of animals administered haloperidol alone and haloperidol with $\mathrm{Zn}$ at 2.5 and $5.0 \mathrm{mg} / \mathrm{kg}$ compared to animals administered vehicle. Administration of $\mathrm{Zn}$ at $2.5 \mathrm{mg} / \mathrm{kg}$ was associated with lesser weight gain when compared to vehicle. Compared to haloperidol however, there was lesser weight gain in groups administered $\mathrm{Zn}$ alone at 2.5 and $5.0 \mathrm{mg} / \mathrm{kg}$ and haloperidol and $\mathrm{Zn}$ at 2.5 and $5.0 \mathrm{mg} / \mathrm{kg}$.

\subsection{Effects of $\mathrm{Zn} / \mathrm{haloperidol}$ administration on horizontal locomotion}

Figure 2 shows the effect of zinc/haloperidol on locomotion in the open-field. Two-factor ANOVA of horizontal locomotion scores revealed a significant main effect of $\mathrm{Zn}$ or haloperidol (drug) $(\mathrm{F}=28.6, \mathrm{p}<0.001)$, duration of administration (acute vs. repeated) ( $\mathrm{F}=144$, $\mathrm{p}<0.001$ ), but no interactions between drug $\mathrm{x}$ duration of administration $(\mathrm{F}=0.988, \mathrm{p}<0.341)$. Pairwise comparisons of the effect of vehicle versus (vs.) drug dose following acute administration revealed a significant increase in horizontal locomotion following administration of $\mathrm{Zn}$ alone at 2.5 $\mathrm{mg} / \mathrm{kg}$, and a significant decrease with haloperidol and haloperidol co-administered with $\mathrm{Zn}$ at 2.5 and $5.0 \mathrm{mg} / \mathrm{kg}$. Repeated administration resulted in significant decrease in locomotor activity with haloperidol, both doses of $\mathrm{Zn}$ alone and when $\mathrm{Zn}(2.5$ and $5.0 \mathrm{mg} / \mathrm{kg})$ was co-administered with haloperidol. Compared to haloperidol however, there was a significant increase in locomotor activity at both doses of $\mathrm{Zn}$ when administered alone or when co-administered with haloperidol.

\subsection{Effects of $\mathrm{Zn} / \mathrm{haloperidol}$ Administration on Rearing}

Figure 3 shows the effect of $\mathrm{Zn} / \mathrm{haloperidol}$ on rearing in the open field. Two-factor ANOVA of rearing scores revealed significant main effect of $\mathrm{Zn}$ and haloperidol (drug) dose $(F=19.00, p<0.001)$, duration of administration (acute vs. repeated) $(\mathrm{F}=314, \mathrm{p}<0.001)$ and strong interactions between $\mathrm{Zn}$ and haloperidol dose $\mathrm{x}$ duration of administration $(\mathrm{F}=19.32, \mathrm{p}<0.005)$. Pairwise comparisons of the effect of vehicle vs. $\mathrm{Zn}$ and haloperidol dose following both acute and repeated administration revealed a significant increase in rearing activity when $\mathrm{Zn}$ was administered at 2.5 $\mathrm{mg} / \mathrm{kg}$, and a decrease with administration of haloperidol, $\mathrm{Zn}$ at $5.0 \mathrm{mg} / \mathrm{kg}$ and when $\mathrm{Zn}(2.5$ and $5.0 \mathrm{mg} / \mathrm{kg})$ was co-administered with haloperidol compared to vehicle.

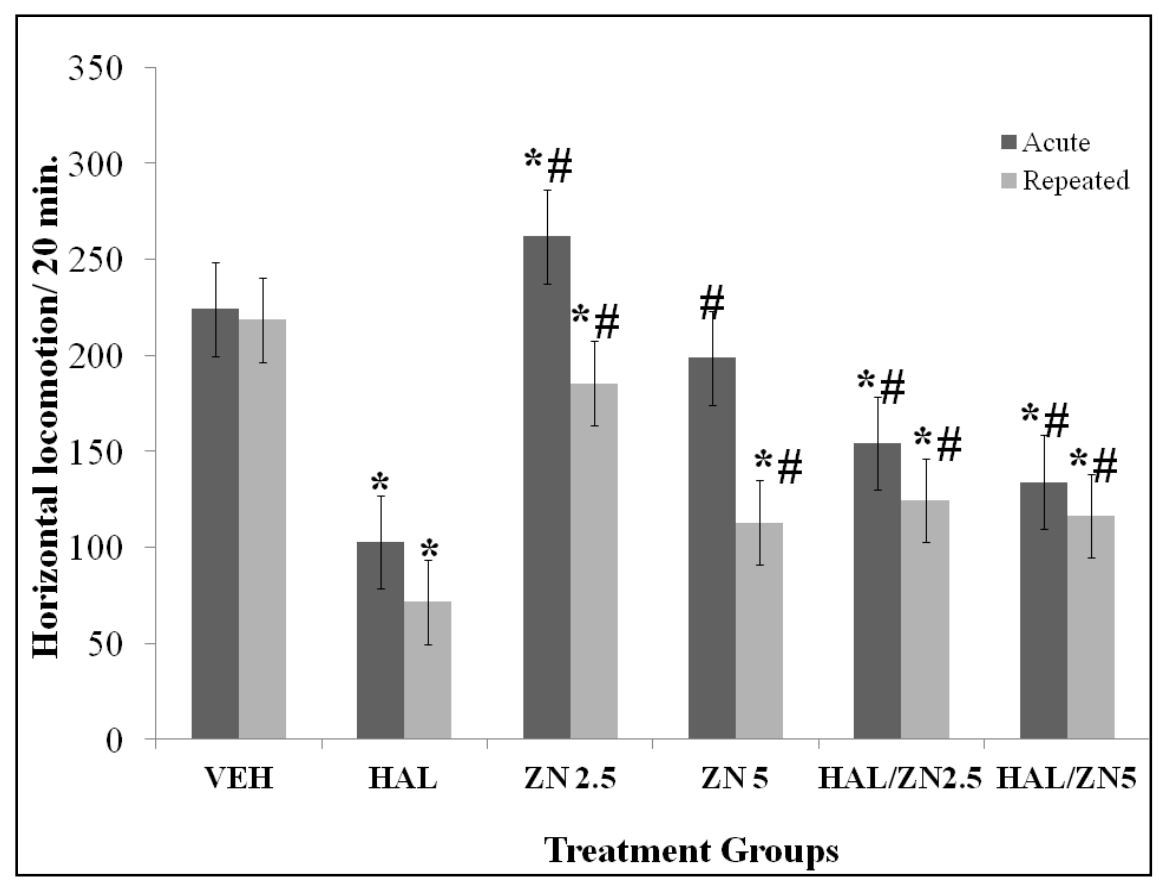

Figure 2. Effects of $\mathrm{Zn} /$ haloperidol administration on horizontal locomotion. Each bar represents mean \pm S.E.M, ${ }^{*} \mathrm{p}<0.05$ vs. VEH, ${ }^{\sharp} \mathrm{p}<0.05$ vs. HAL, number of mice per treatment group =12, VEH: Vehicle, HAL: Haloperidol, ZN: Zinc, HAL/ZN: Haloperidol Zn co-administration. 


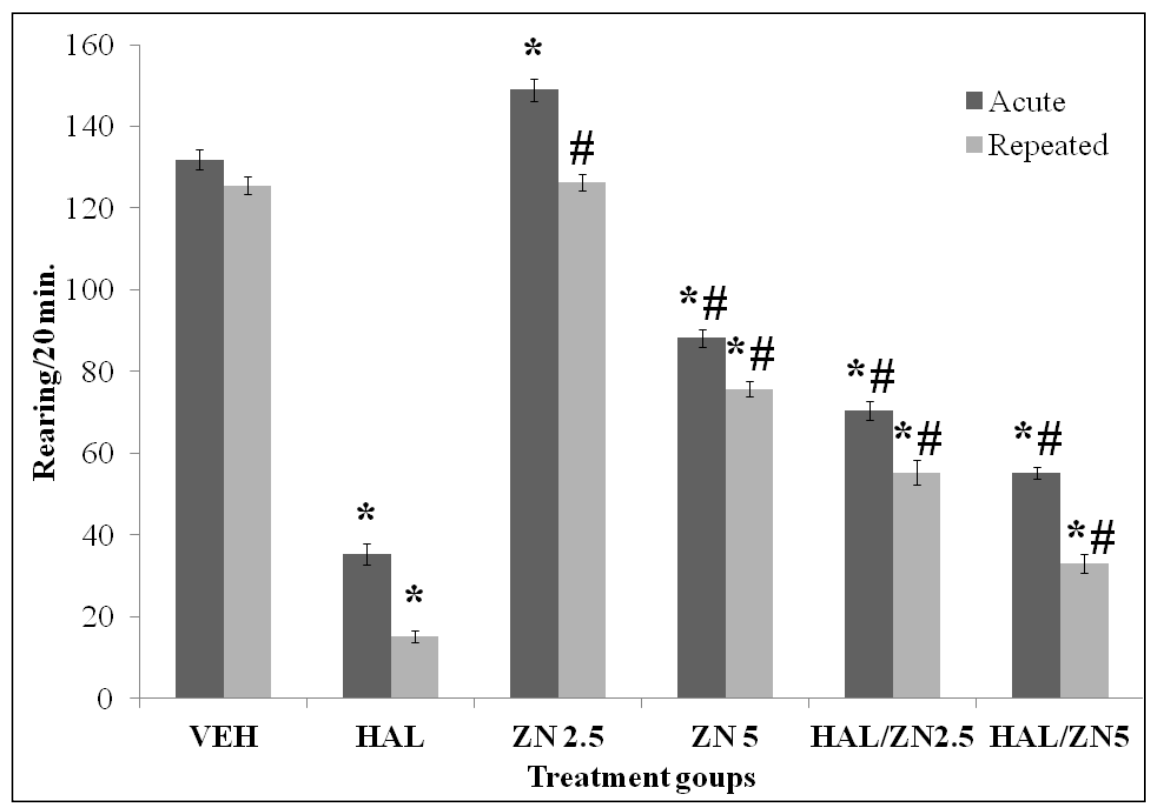

Figure 3. Effects of $\mathrm{Zn} / \mathrm{haloperidol} \mathrm{administration} \mathrm{on} \mathrm{rearing} \mathrm{activity.} \mathrm{Each} \mathrm{bar} \mathrm{represents} \mathrm{mean} \pm$ S.E.M, ${ }^{*} \mathrm{p}<0.05$ vs. VEH, ${ }^{*} \mathrm{p}<0.05$ vs. HAL, number of mice per treatment group =12, VEH: Vehicle, HAL: Haloperidol, ZN: Zinc, HAL/ZN: Haloperidol Zn co-administration

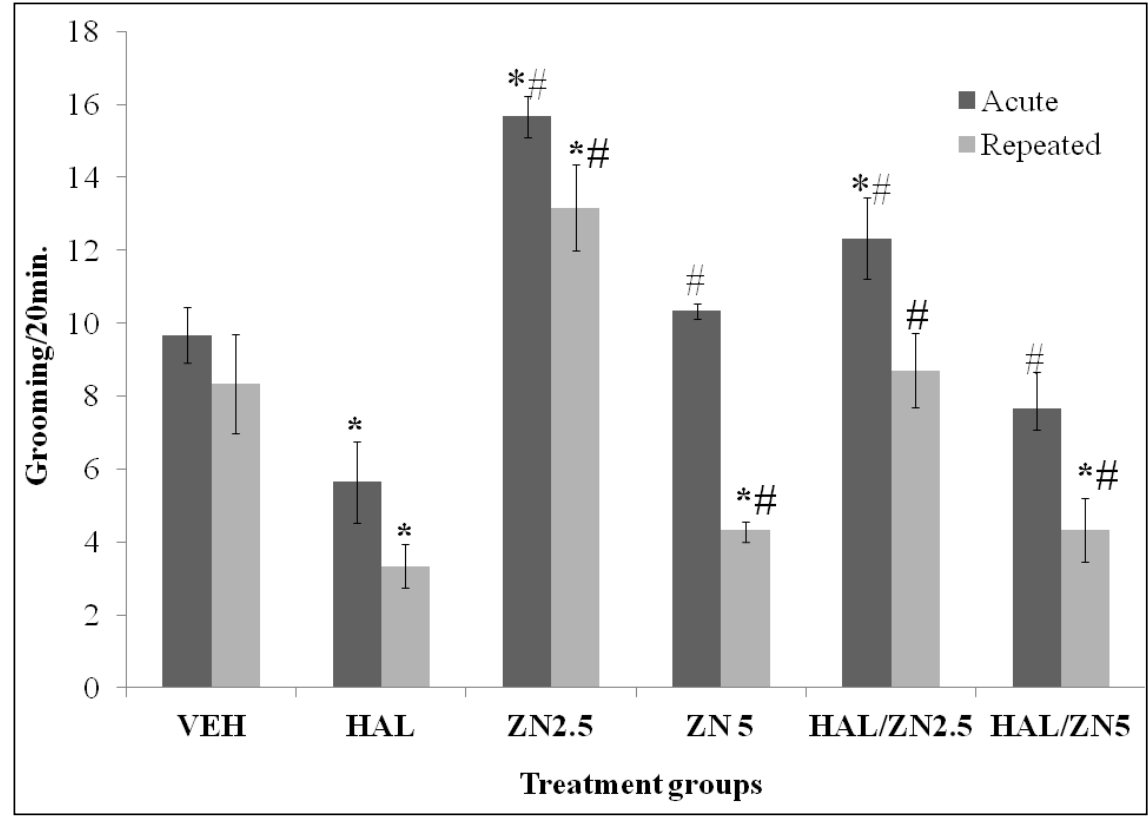

Figure 4. Effects of $\mathrm{Zn} / \mathrm{haloperidol} \mathrm{administration} \mathrm{on} \mathrm{grooming} \mathrm{behaviour.} \mathrm{Each} \mathrm{bar} \mathrm{represents} \mathrm{mean} \pm$ S.E.M, ${ }^{*} \mathrm{p}<0.05$ vs. VEH, ${ }^{\#} \mathrm{p}<0.05$ vs. HAL, number of mice per treatment group =12, VEH: Vehicle, HAL: Haloperidol, ZN: Zinc, HAL/ZN: Haloperidol/Zn co-administration.

\subsection{Effects of $\mathrm{Zn} / \mathrm{haloperidol}$ Administration on Grooming}

Figure 4 shows the effect of $\mathrm{Zn} / \mathrm{haloperidol}$ on grooming in the open field. Two-factor ANOVA of grooming scores revealed a significant main effect of $\mathrm{Zn}$ and haloperidol dose $(\mathrm{F}=38.2, \mathrm{p}<0.001)$, significant effect of duration of administration (acute vs. repeated) $(\mathrm{F}=83.4, \mathrm{p}<0.004)$ and strong interactions between $\mathrm{Zn}$ and haloperidol dose $\mathrm{x}$ duration of administration $(F=16.20, p<0.002)$. Pairwise comparisons of the effect of vehicle vs. zinc and haloperidol dose following acute administration showed significant increase in grooming when $\mathrm{Zn}$ was administered at 2.5 $\mathrm{mg} / \mathrm{kg}$ and when $\mathrm{Zn}(2.5 \mathrm{mg} / \mathrm{kg})$ was co-administered with haloperidol, while a decrease was seen with haloperidol compared to vehicle. Repeated administration revealed a significant increase in grooming when $\mathrm{Zn}$ was administered at $2.5 \mathrm{mg} / \mathrm{kg}$ and a decrease with haloperidol, $\mathrm{Zn}$ at 5.0 $\mathrm{mg} / \mathrm{kg}$ and when $\mathrm{Zn}$ at $5.0 \mathrm{mg} / \mathrm{kg}$ was co-administered with haloperidol. Compared to haloperidol however, there was a significant increasing in grooming at both doses of $\mathrm{Zn}(2.5$ and $5.0 \mathrm{mg} / \mathrm{kg}$ ) when either administered alone or co-administered with haloperidol. 


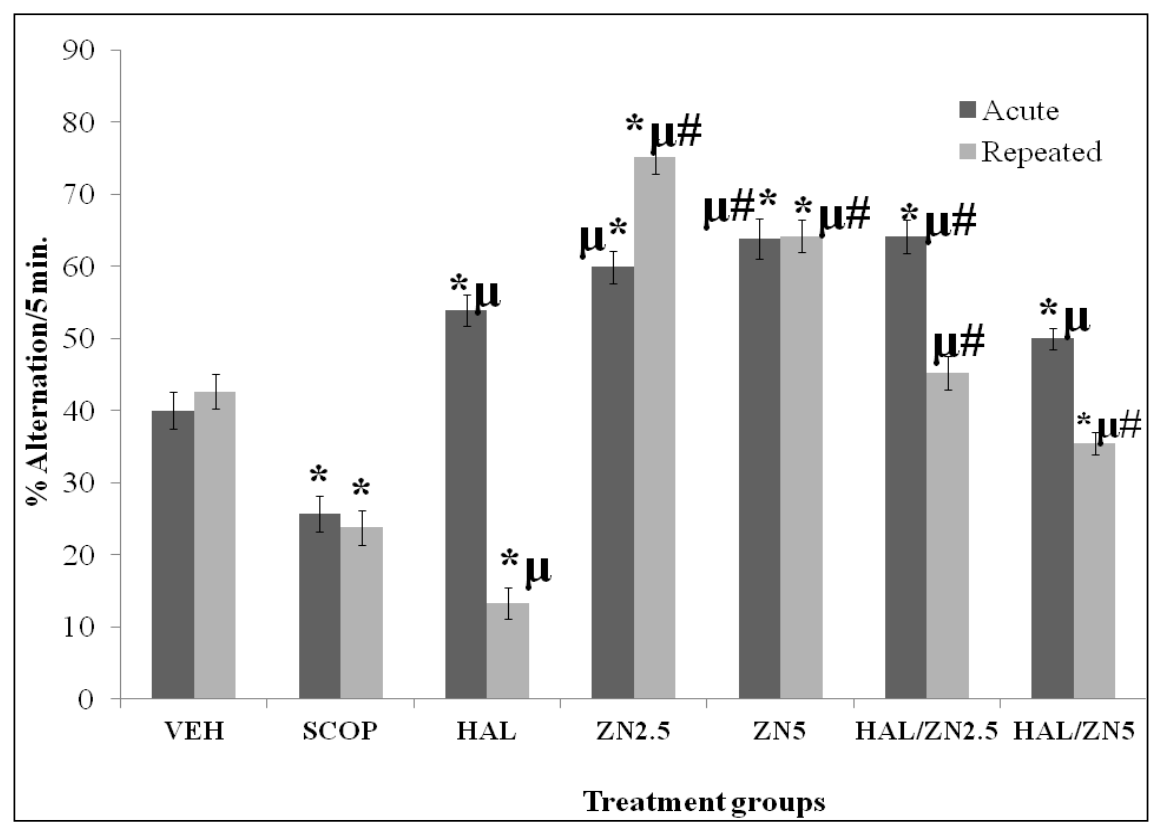

Figure 5. Effects of $\mathrm{Zn}$ /haloperidol administration on $\mathrm{Y}$-maze memory tasks. Each bar represents mean $\pm \mathrm{S} . \mathrm{E} . \mathrm{M},{ }^{*} \mathrm{p}<0.05 \mathrm{vs}$. VEH, ${ }^{\mu} \mathrm{p}<0.05 \mathrm{vs}$. SCOP, ${ }^{\#} \mathrm{p}<0.05$ vs. HAL, number of mice per treatment group =12; VEH: Vehicle, SCOP: scopolamine HAL: Haloperidol, ZN: Zinc, HAL/ZN: Haloperidol/Zn co-administration.

\subsection{Effect of $\mathrm{Zn} / \mathrm{haloperidol} \mathrm{Administration} \mathrm{on} \mathrm{Y-maze}$ Spatial Working-memory Tasks}

Figure 5 shows the effect of $\mathrm{Zn} /$ haloperidol administration on $\%$ alternation in the Y-maze. Two-factor ANOVA revealed significant main effect of $\mathrm{Zn}$ and haloperidol dose $(\mathrm{F}=44.1, \mathrm{p}<0.001)$, significant effect of duration of administration (acute vs. repeated) $(\mathrm{F}=8.16, \mathrm{p}<0.013)$ and no interactions between $\mathrm{Zn}$ and haloperidol dose $\mathrm{x}$ duration of administration $(\mathrm{F}=1.90, \mathrm{p}<0.541)$. Pairwise comparisons of the effect of vehicle vs. scopolamine (SCOP), $\mathrm{Zn}$ or haloperidol dose following acute administration revealed a significant decrease in memory scores (measured as \% alternation) with SCOP and a significant increase with haloperidol, $\mathrm{Zn}$ at both doses (2.5 and $5.0 \mathrm{mg} / \mathrm{kg}$ ), when administered alone or when co-administered with haloperidol. Repeated administration of vehicle, scopolamine, $\mathrm{Zn}$ or haloperidol resulted in a significant decrease in memory scores with SCOP and haloperidol and a significant increase with $\mathrm{Zn}(2.5$ and $5.0 \mathrm{mg} / \mathrm{kg})$ when administered alone or when $\mathrm{Zn}(5.0 \mathrm{mg} / \mathrm{kg})$ was co-administerd with haloperidol, compared to vehicle.

In comparison to SCOP, there was a significant increase in memory scores with haloperidol and $\mathrm{Zn}$ (at 2.5 and 5.0 $\mathrm{mg} / \mathrm{kg}$ ) when acutely administered either alone, or co-administered with haloperidol. Repeated administration revealed a significant decrease in memory scores with haloperidol and an increase with both doses of $\mathrm{Zn}$ administered alone or co-administered with haloperidol. In comparison to haloperidol, there was a significant increase in memory task scores with $\mathrm{Zn}$ at $5.0 \mathrm{mg} / \mathrm{kg}$ alone and when $\mathrm{Zn}$ at $2.5 \mathrm{mg} / \mathrm{kg}$ was co-administered with haloperidol, following acute administration. Repeated administration revealed a significant increase at both doses (2.5 and 5.0 $\mathrm{mg} / \mathrm{kg}$ ) of $\mathrm{Zn}$, either administered alone or co-administered with haloperidol.

\subsection{Effect of $\mathrm{Zn} / \mathrm{haloperidol}$ Administration on Radial Arm-maze Spatial Working-memory Tasks}

Figures 6 shows the effect of $\mathrm{Zn} /$ haloperidol administration on alternation index in the radial-arm maze, measured as alternation index $/ 5$ minute, which is a fraction of number of correct alternation before first error and total number of alternations made in a five minute period. Two-factor ANOVA revealed significant main effect of $\mathrm{Zn}$ and haloperidol dose $(F=50.4, p<0.001)$, significant effect of duration of administration (acute vs. repeated) $(\mathrm{F}=7.98$, $\mathrm{p}<0.005)$ and no interactions between $\mathrm{Zn}$ and haloperidol dose $\mathrm{x}$ duration of administration $(\mathrm{F}=1.91, \mathrm{p}<0.08)$. Pairwise comparisons of the effect of vehicle vs. scopolamine (SCOP), $\mathrm{Zn}$ or haloperidol dose following acute administration revealed a significant decrease in memory scores (measured as \% alternation) with SCOP and a significant increase with $\mathrm{Zn}$ at both doses $(2.5$ and $5.0 \mathrm{mg} / \mathrm{kg})$ when administered alone, and when $\mathrm{Zn}$ at $2.5 \mathrm{mg} / \mathrm{kg}$ was co-administered with haloperidol. Repeated administration of vehicle, scopolamine $\mathrm{Zn}$ or haloperidol resulted in a significant decrease in memory scores with SCOP and haloperidol and a significant increase with $\mathrm{Zn}$ at $2.5 \mathrm{mg} / \mathrm{kg}$ when administered alone or co-administered with haloperidol, compared to vehicle.

In comparison to SCOP, there was a significant increase in memory task scores with haloperidol, $\mathrm{Zn}$ (at 2.5 and 5.0 $\mathrm{mg} / \mathrm{kg}$ ) when administered alone, and when $\mathrm{Zn}$ at $2.5 \mathrm{mg} / \mathrm{kg}$ was co-administered with haloperidol acutely. Repeated 
administration revealed a significant decrease with haloperidol and an increase with $\mathrm{Zn}$ at $2.5 \mathrm{mg} / \mathrm{kg}$ when administered alone or co-administered with haloperidol. Compared to haloperidol, there was a significant increase in memory scores with $\mathrm{Zn}$ at 2.5 and $5.0 \mathrm{mg} / \mathrm{kg}$ when administered either alone or co-administered with haloperidol following both acute and repeated administration.

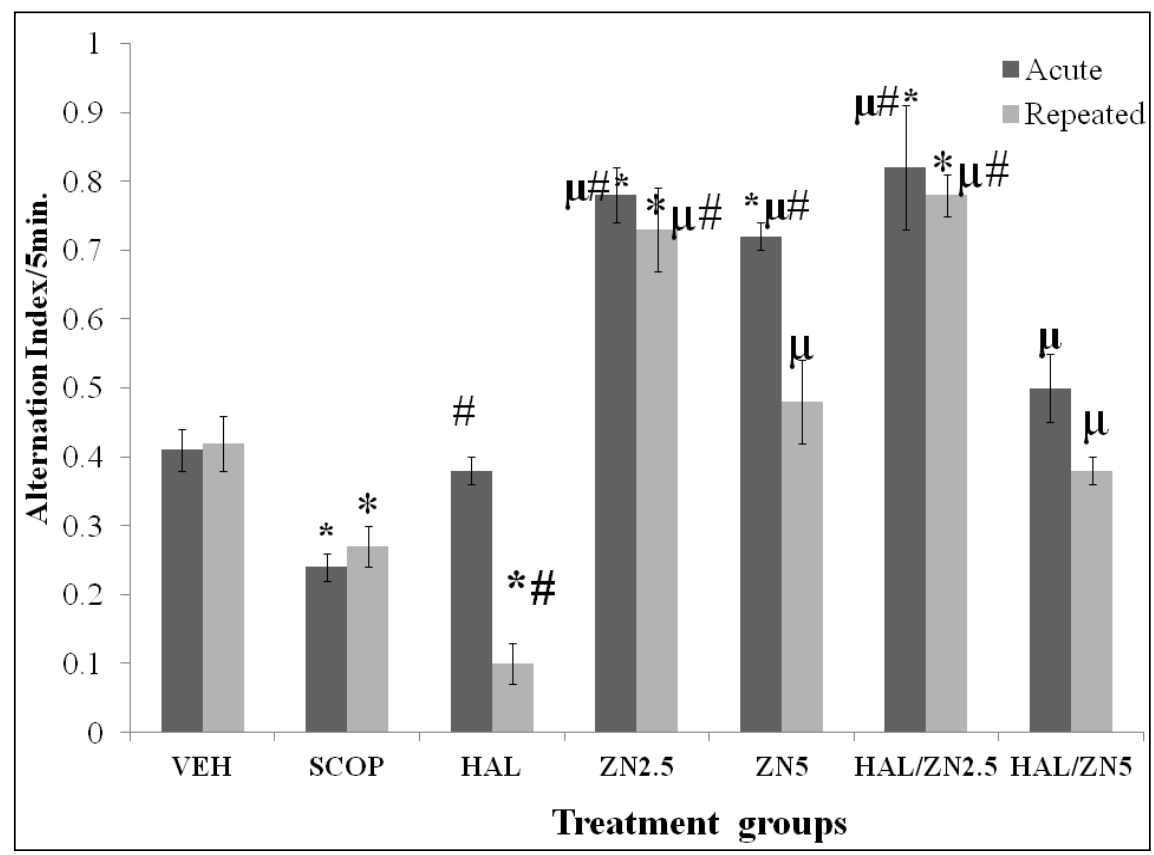

Figure 6. Effects of $\mathrm{Zn} /$ haloperidol administration on radial arm maze memory tasks. Each bar represents mean \pm S.E.M, ${ }^{*} \mathrm{p}<0.05$ vs. VEH, ${ }^{\#} \mathrm{p}<0.05 \mathrm{vs}$. SCOP, ${ }^{\mu} \mathrm{p}<0.05$ vs. HAL, number of mice per treatment group $=12$; VEH: Vehicle, SCOP: scopolamine, Haloperidol, ZN: Zinc, HAL/ZN: Haloperidol/Zn co-administration.

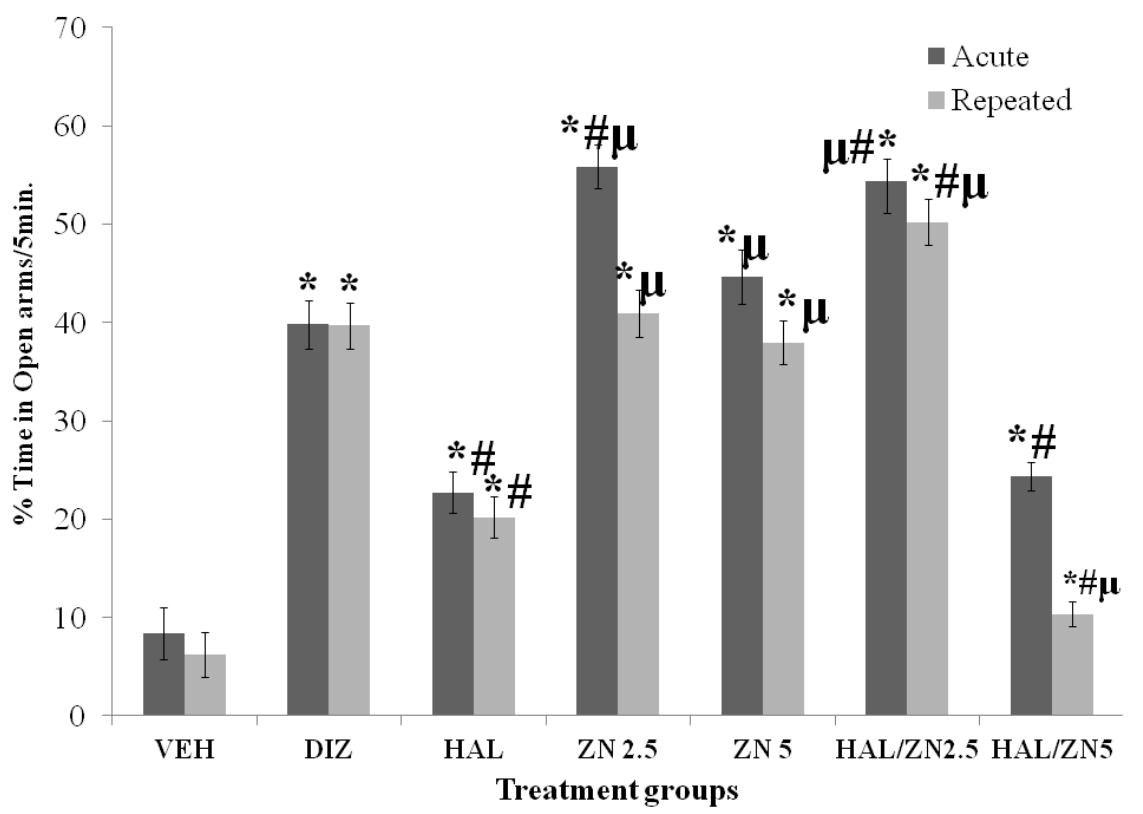

Figure 7. Effects of $\mathrm{Zn} /$ haloperidol administration on $\%$ time spent in the open arm of the elevated plus maze. Each bar represents mean \pm S.E.M, ${ }^{*} \mathrm{p}<0.05$ vs. VEH, ${ }^{*} \mathrm{p}<0.05$ vs. DIZ, ${ }^{\mu} \mathrm{p}<0.05$ vs. HAL, number of mice per treatment group $=12$; VEH: Vehicle, DIZ: diazepam, Haloperidol, ZN: Zinc, HAL/ZN: Haloperidol/Zn co-administration. 


\subsection{Effect of $\mathrm{Zn} / \mathrm{haloperidol}$ Administration on Anxiety Behaviour}

Figure 7 shows the effect of $\mathrm{Zn} /$ haloperidol administration on \% time spent in the open arm of the EPM. Two-factor ANOVA revealed a significant main effect of $\mathrm{Zn}$ and haloperidol dose $(\mathrm{F}=49.00, \mathrm{p}<0.001)$, duration of administration (acute vs. repeated) $(\mathrm{F}=39.2, \mathrm{p}<0.001)$ and strong interactions between $\mathrm{Zn}$ and haloperidol dose $\mathrm{x}$ duration of administration $(F=33.25, p<0.002)$. Pairwise comparisons of the effect of vehicle against diazepam (DIZ), $\mathrm{Zn}$ or haloperidol dose, following acute administration revealed a significant increase in time spent in the open arms with DIZ, haloperidol, and $\mathrm{Zn}$ at both doses (2.5 and 5/0 $\mathrm{mg} / \mathrm{kg}$ ) when administered either alone or co-administered with haloperidol, with both acute and repeated administration. In comparison to DIZ, there was a significant decrease in time spent in the open arms with haloperidol and following $\mathrm{Zn}$ at $5.0 \mathrm{mg} / \mathrm{kg}$ co-administered with haloperidol following acute and repeated administration. There was a significant increase in open arm time with $\mathrm{Zn}$ at $2.5 \mathrm{mg} / \mathrm{kg}$ administered alone or co-administered with haloperidol following acute administration, and with $\mathrm{Zn}$ at $2.5 \mathrm{mg} / \mathrm{kg}$ co-administered with haloperidol, following repeated administration. In comparison to haloperidol, there was a significant increase in time spent in the open arms with $\mathrm{Zn}$ at 2.5 and $5.0 \mathrm{mg} / \mathrm{kg}$ administered alone and with $\mathrm{Zn}$ at 2.5 $\mathrm{mg} / \mathrm{kg}$ co-administered with haloperidol, following acute and repeated administration. A significant decrease was seen compared to haloperidol when $\mathrm{Zn}$ at $5.0 \mathrm{mg} / \mathrm{kg}$ was co-administered with haloperidol following repeated administration.

\section{Discussion}

Unwanted behavioural side-effects constitute one of the limitations to the use of antipsychotic medications; therefore, research has continued on the path of discovering newer and better drugs. However, the newer drugs tend to have their own side-effects, therefore, they may not necessarily be the 'magic bullet' that is desired. Recent breakthroughs in the understanding of the pathogenesis of several mental illnesses point to imbalances or deficiencies of trace elements in the body. Of these, $\mathrm{Zn}$ has received a certain degree of attention; and some researchers are of the opinion that correction of bodily $\mathrm{Zn}$ deficiency may be crucial to management of schizophrenia [15]. Zn supplementation may be a beneficial adjunct to standard medications; however, there is a need to first understand the behavioural phenotype that is expressed by $\mathrm{Zn}$ administration alone, and in co-administration with a standard medication in health. Using healthy mice, we chose to investigate the potentials of $\mathrm{Zn}$ as a modulator of the behavioural effects of a standard antipsychotic. The aim was to document the ability of $\mathrm{Zn}$ to reduce unwanted behavioural effects of haloperidol in health; thereby allowing a clearer perspective when both are co-administered as therapy.

In our study, we utilized mixed-gender mice in order to be able to extrapolate our results to humans generally and also because psychiatric disorders affect both genders of humans. Behavioural indices that were measured in this study were open field novelty-induced behaviours, working-memory and anxiety. Our results show that (1) significant weight gain was observed with haloperidol, and a lesser weight gain seen with $\mathrm{Zn}$ /haloperidol co-administration (2) open-field exploration and grooming were suppressed by haloperidol; these effects were reversed to varying extents with $\mathrm{Zn}$ (3) haloperidol-induced memory-impairment in the $\mathrm{Y}$-maze and radial-arm maze was significantly attenuated by $\mathrm{Zn}$ (4) anxiolytic potential of haloperidol is significantly boosted by $\mathrm{Zn}$.

In this study, administration of haloperidol caused a significant increase in weight compared to vehicle. $\mathrm{Zn}$ supplementation in this study was associated with lesser weight gain compared to weight changes seen with haloperidol. Co-administration of zinc with haloperidol however resulted in increased weight gain compared to $\mathrm{Zn}$ alone groups, although this was a significant reduction from haloperidol-associated weight gain. Weight gain is one of the documented side-effects of haloperidol [33], although compared to other antipsychotics; haloperidol has been less consistently associated with weight gain [34]. There have been reports of increase weight with haloperidol $[35,36]$, and there is also documentation of no weight gain [37]. In the last decade or more, reports of a link between beneficial therapeutic response and treatment-emergent weight gain have been seen [36]. The underlying mechanisms involved in antipsychotic-induced weight gain however are still a subject of extensive debates. Although increase in food or calorie intake, fat deposition hormones and peptides have been considered as possible causes, the main biological mechanisms are largely unknown. Management of antipsychotic-induced weight gain has become important largely due to the complications of uncontrolled weight gain [38]. More recently, behavioural and non-pharmacologic interventions have been considered [39]. The ability of $\mathrm{Zn}$ to curb excess weight gain if used as a therapeutic adjunct will be of immense benefit, clinically.

Administration of haloperidol in this study resulted in central inhibition (with acute and repeated administration). Horizontal locomotion and rearing were depressed compared to vehicle; this correlates with results of previous studies that concluded that haloperidol exerted a depressant effect on general explorative ability [40,41]. Zn supplementation in this study caused a mixed response, with an initial increase in locomotor activity and rearing at $2.5 \mathrm{mg} / \mathrm{kg}$ following acute administration, leading to a decrease with repeated administration; although, no significant difference was seen in locomotor activity and rearing at $5 \mathrm{mg} / \mathrm{kg}$ (acute) and 2.5 $\mathrm{mg} / \mathrm{kg}$ (repeated administration) respectively. The results seen with $\mathrm{Zn}$ administration in this study confirms that $\mathrm{Zn}$ supplementation can significantly alter behaviour in animals; and is consistent with other studies that have reported an 
acute increase in locomotor activity which later transforms to no significant effect or a decrease in response, usually with repeated administration of $\mathrm{Zn}$ [42-45]. Co-administration of zinc with haloperidol however resulted in an improvement in locomotor activity and rearing compared to that seen with haloperidol alone, although at no time did the values return to baseline (vehicle).

The roles of dopamine, dopamine receptors [41] and $\mathrm{N}$-methyl-D-aspartate (NMDA) receptors [46,47] in the regulation of locomotor activity, emotionality, motivation and memory have been studied extensively. $\mathrm{Zn}$ is an NMDA receptor inhibitor that accumulates within the synaptic vesicles of some glutamatergic neurons and modulates neuronal excitability and synaptic plasticity by multiple mechanisms that are poorly understood. Haloperidol on the other hand is a dopamine receptor antagonist [48]. The co-administration of both drugs tempered the hypolocomotion seen when haloperidol is given alone; the mechanisms responsible for these may not be unrelated to Zn's ability to modulate both excitatory and inhibitory neurotransmission [49]. While excitatory NMDA receptors are directly inhibited by $\mathrm{Zn}$, non-NMDA receptors appear unaffected by this inhibition. In contrast, $\mathrm{Zn}$ potentiates GABA (A) receptor-mediated inhibitory transmission, influencing transmitter release. Finally, studies have shown that both direct and indirect stimulation of dopamine $\left(\mathrm{D}_{1}\right)$ receptors can increase locomotor activity in mice [50], whereas $\mathrm{Zn}$ can inhibit antagonist binding to $\mathrm{D}_{1}$ receptors via allosteric modulation of the binding site.

Grooming is an important and 'ancient' behaviour observed in a number of animals. In this study, a decrease in grooming frequency was seen with haloperidol, which is consistent with a general dopamine receptor depolarizing blockade effect seen with haloperidol administration. On the other hand, $\mathrm{Zn}$ administration caused an increase in grooming. Co-administration of $\mathrm{Zn}$ and haloperidol also increased grooming above what was seen with haloperidol, and at $2.5 \mathrm{mg} / \mathrm{kg}$, effect was higher than baseline (vehicle). Dopamine is important in ensuring sequential grooming patterns [51] and activation of $D_{1}$ receptors result in intense grooming [52]. GABA (A or B) receptor activation however reduces grooming behaviour [53]. An inhibitory effect of $\mathrm{Zn}$ on GABA (A) receptors or its possible effect on $D_{1}$ dopamine receptors may be responsible for the increase in grooming that was seen; haloperidol on the other hand has low affinities for brain $\mathrm{D}_{1}$ receptors [54].

The results of spatial working-memory tests (Y-maze, radial-arm maze) revealed memory-impairment with repeated administration of haloperidol, although, acute administration of haloperidol in the Y-maze appeared to improve memory; with $\mathrm{Zn}$, both acute and repeated administration showed memory-enhancement. Co-administration of $\mathrm{Zn}$ with haloperidol at both doses showed memory- enhancement compared to haloperidol, although lower than baseline (vehicle). Haloperidol-induced memory-deficits had been previously documented, therefore the effect seen here is in agreement with those of previous studies that have also reported memory-deficits with repeated haloperidol use [2,54]. On the other hand, $\mathrm{Zn}$ had been reported to modulate both ion channels and synaptic plasticity, making it important in both learning and memory [55]. Working-memory is regulated by a number of brain regions (such as hippocampus and prefrontal cortex) through effects of cholinergic, glutamatergic or $\gamma$ amino butyric acid (GABAergic) projections to these sites [56]. Activation of GABAergic impulses impairs spontaneous alternation working-memory, while increased cholinergic and glutamatergic transmission improves working-memory [57]. The effect of $\mathrm{Zn}$ on memory may be mediated through its effects on either GABA or glutamate receptors.

$\mathrm{Zn}$ administration has been reported to be anxiolytic [45,58], and this is also evident in this study. Haloperidol administration also resulted in an anxiolytic effect, although the effect was much lower than what was seen with diazepam. $\mathrm{Zn}$ supplementation had a more profound anxiolytic effect compared to either haloperidol or diazepam, while co-administration of $\mathrm{Zn}$ at $2.5 \mathrm{mg} / \mathrm{kg}$ with haloperidol resulted in anxiolysis that exceeded that seen with both diazepam and haloperidol. A complex, multi-feedback mechanism [59] involving serotonin, dopamine, glutamate, GABA and norepinephrine have been implicated in anxiety-related disorders [60]. The response seen with the administration of $\mathrm{Zn}$ may be a consequence of its effects on GABA (A) or at the NMDA receptors, both of which are critical to anxiety states.

\section{Conclusions}

This study concludes that co-administration of haloperidol with $\mathrm{Zn}$ can reduce some unwanted behavioural effects that are known to be associated with haloperidol therapy; hence zinc may be a beneficial adjunct to haloperidol administration. To ensure its suitability as an adjunct antipsychotic, more studies need to be carried out in assessing the effects of $\mathrm{Zn} / \mathrm{haloperidol}$, in an animal model of psychosis.

\section{Conflict of Interest}

All authors of this paper declare that there is no conflict of interest related to the content of this manuscript.

\section{Source of Funding}

This research did not receive any specific grant from agencies in the public, commercial, or not-for-profit sectors. 


\section{REFERENCES}

[1] RJ Baldessarini. Drugs acting on the central nervous system, Goodman Gilman's Textbook on Pharmacology. 11th ed. USA: McGraw Hill Publishers. 317-99, 2006.

[2] OM.E Abdel-Salam, ME El-Shamarka, NA. Salem, AEMK El-Mosallamy, AA Sleem Amelioration of the haloperidol-induced memory impairment and brain oxidative stress by cinnarizine. Excli. J. 11:517-530, 2012.

[3] A Stuchlik, L Rehakova, L Rambousek, J Svoboda, K Vales. Manipulation of D2 receptors with quinpirole and sulpiride affects locomotor activity before spatial behavior of rats in an active place avoidance task. Neurosci Res. 58:133-9, 2007

[4] SN Von Huben, SA Davis, CC Lay, SN Katner, RD Crean, MA Taffe. Differential contributions of dopaminergic D1and D2-like receptors to cognitive function in rhesus monkeys. Psychopharmacol. (Berl). 188:586-96, 2006.

[5] G Di Chiara, V Bassareo, S Fenu, MA De Luca, L Spina, C Cadoni, E Acquas, E Carboni, V Valentini, D Lecca. Dopamine and drug addiction: the nucleus accumbens shell connection. Neuropharmacol. 47 Suppl 1:227-41, 2004.

[6] VM Simon, A Parra, J Minarro, MC Arenas, C Vinader-Caerols, MA Aguilar. Predicting how equipotent doses of chlorpromazine, haloperidol, sulpiride, raclopride and clozapine reduce locomotor activity in mice. Eur. Neuropsychopharmacol. 10:159-164, 2000.

[7] JL Wiley, BR Martin. Cannabinoid pharmacological properties common to other centrally acting drugs. Eur. J. Pharmacol. 471:185-193, 2003.

[8] JM Witkin, N Savtchenko, M Mashkovsky, M Beekman, P Munzar, M Gasior, SR Goldberg, JT Ungard, J Kim, T Shippenberg, V Chefer. Behavioral, toxic, and neurochemical effects of sydnocarb, a novel psychomotor stimulant: Comparisons with methamphetamine. JPET 288(3)1298-1310, 1999.

[9] AV Terry Jr, WD Hill, V Parikh, JL Waller, DR Evans, SP Mahadik. Differential effects of haloperidol, risperidone, and clozapine exposure on cholinergic markers and spatial learning performance in rats. Neuropsychopharmacol. 28:300-9, 2003.

[10] Y Hou, CF Wu, JY Yang, T Guo. Differential effects of haloperidol, clozapine and olanzapine on learning and memory functions in mice. Prog Neuropsychopharmacol Biol Psychiatry.30:1486-95, 2006.

[11] OME Abdel-Salam, SA Nada. Effect of piracetam, vinpocetine and ginkgo biloba on antipsychotic-induced impairment of learning and memory. Ceska a Slovenska Neurologie a Neurochirurgie. 74:29-35, 2011.

[12] E Legangneux, J McEwen, K Wesnes, L Berougnan, N Miget, M Canal. The acute effects of amisulpride $(50 \mathrm{mg}$ and $200 \mathrm{mg}$ ) and haloperidol (2 mg) on cognitive function in healthy elderly volunteers. J Psychopharmacol. 14:164-71, 2000 .

[13] C Lustig, WH Meck. Chronic treatment with haloperidol induces deficits in working memory and feedback effects of interval timing. Brain Cogn. 58:9-16, 2005.
[14] SE Lakhan, KF Vieira, Nutritional therapies for mental disorders. Nutr J. 7: 2, 2008. doi: 10.1186/1475-2891-7-2

[15] DO Rudin. The dominant diseases of modernized societies as omega-3 essential fatty acid deficiency syndrome: substrate beriberi. Med Hypotheses. 8:17-47, 1982. doi: 10.1016/0306-9877(82)90088-3.

[16] IR Bell, JS Edman, FD Morrow, DW Marby, S Mirages, G Perrone, HL Kayne, JO Cole. B complex vitamin patterns in geriatric and young adult inpatients with major depression. $\mathrm{J}$ Am Geriatr Soc. 39:252-257, 1991.

[17] GA Eby, KL Eby. Rapid recovery from major depression using magnesium treatment. Med Hypotheses. 67:362-370, 2006. doi: 10.1016/j.mehy.2006.01.047

[18] DP Hale, TR Test Sr. the role of zinc supplementation in the treatment of schizophrenia J. Soc. Cogn. Psycho. 1(12), 1-12, 2010.

[19] SN Young. Folate and depression: A neglected problem. J Psychiatry Neurosci. 32:80-82, 2007.

[20] AS Prasad. Zinc: An overview. Nutrition, 11:93-9, 1995.

[21] W Maret, HH Sandstead.. Zinc requirements and the risks and benefits of zinc supplementation. J Trace Elem Med Biol. 20:3-18, 2006.

[22] HH Sandstead. Understanding zinc: recent observations and interpretations. J Lab Clin Med 124:322-7,1994.

[23] Institute of Medicine, Food and Nutrition Board. Dietary Reference Intakes for Vitamin A, Vitamin K, Arsenic, Boron, Chromium, Copper, Iodine, Iron, Manganese, Molybdenum, Nickel, Silicon, Vanadium, and Zinc. Washington, DC: National Academy Press, 2001

[24] R Jayawardena, P Ranasinghe, P Galappatthy, RLDK Malkanthi, GR Constantine, P Katulanda. Effects of zinc supplementation on diabetes mellitus: A systematic review and meta-analysis. Diabetol. Metab. Syndrome 4:13, 2012.

[25] E Ranjbar, MS Kasaei, M Mohammad-Shirazi, J Nasrollahzadeh, B Rashidkhani, J Shams, S Mostafavi, MR Mohammadi. Effects of Zinc Supplementation in Patients with Major Depression: A Randomized Clinical Trial. Iran J Psychiatry. 8(2): 73-79, 2013.

[26] D Farzin, N Mansouri, T Yazdani. Elevated plasma copper/zinc ratios in patients with schizophrenia. Eur. Neuropsychopharmacol 16(4), S364-S365, 2006.

[27] JE Kaslow. Zinc deficiency and metabolism. 2010. www.drkaslow.com/html/zinc.html

[28] Zinc, Fact sheet, Office of dietary supplements, National institute of health, USA, usa.gov, 2016

[29] S Kapur, SC VanderSpek, BA Brownlee, JN Nobrega. Antipsychotic dosing in preclinical models is often unrepresentative of the clinical condition: a suggested solution based on in vivo occupancy. J Pharmacol Exp Ther 305:625-631, 2003.

[30] OJ Onaolapo, AY Onaolapo, MA Akanmu, G Olayiwola. Foraging enrichment modulates open field response to monosodium glutamate in mice, Annal. Neurosci. 22(3): 162-170, 2015. 
[31] OJ Onaolapo, AY Onaolapo, OR Akinola, TO Anisulowo. Dexamethasone regimens alter spatial memory and anxiety levels in mice; J.Behav. Brain Sc., 4, 159-167, 2014.

[32] OJ Onaolapo, AY Onaolapo, EO Awe, N Jibunor, B Oyeleke, AJ Ogedengbe. Oral artesunate-amodiaquine combination causes anxiolysis and impaired cognition in healthy Swiss mice. IOSR: JPBS 7(2): 97-102, 2013.

[33] Haloperidol Fact sheet, National alliance on mental illness. Minnesota, www.namihelps.org, 2007.

[34] JW Newcomer. Second-generation (atypical) antipsychotics and metabolic effects: a comprehensive literature review. CNS Drugs. 19(Suppl 1): 1-93, 2005.

[35] R Perez-Iglesias, B Crespo-Facorro, O Martinez-Garcia, ML Ramirez-Bonilla, M Alvarez-Jimenez, JM Pelayo-Teran, MT Garcia-Unzueta, JA Amado, KL Vazquez-Barquero. Weight gain induced by haloperidol, risperidone and olanzapine after 1 year: findings of a randomized clinical trial in a drug-naïve population. Schizophr Res. 99(1-3):13-2.2008.

[36] H Ascher-Svanum, M Stensland, Z Zhao, BJ Kinon. Acute weight gain, gender, and therapeutic response to antipsychotics in the treatment of patients with schizophrenia. BMC Psychiatry 5:3, 2005.

[37] B Pouzet, T Mow, M Kreilgaard, S Velschow. Chronic treatment with antipsychotics in rats as a model for antipsychotic-induced weight gain in human. Pharmacol Biochem Behav. 75(1):133-40, 2003.

[38] R Huxley, S Mendis, E Zheleznyakov, S Reddy, J Chan. Body mass index, waist circumference and waist: hip ratio as predictors of cardiovascular risk-a review of the literature. Eur J Clin Nutr 64; 16-22, 2010.

[39] L Maayan, CU Correll. Management of Antipsychotic-Related Weight Gain Expert Rev Neurother. 10(7): 1175-1200, 2010.

[40] U Schmitt, N Dahmen, V Fischer, H Weigmann, ML Rao, S Reuss, C Hiemke. Chronic oral haloperidol and clozapine in rats: A behavioral evaluation. Neuropsychobiol. 139:86-91, 1999.

[41] C Spielewoy, C Roubert, M Hamon, M Nosten, C Betancur, B Giros. Behavioural disturbances associated with hyperdopaminergia in dopamine-transporter knockout mice. Behav Pharmacol. 11(3-4): 279-290, 2000.

[42] B Kroczka, A Zieba, D Dudek, A Pilc, G Nowak. Zinc exhibits an antidepressant-like effect in the forced swimming test in mice. Pol J Pharmacol. 52(5):403-6, 2000.

[43] HS Al -Amary. Behavioral Assessment of Mice Treated with Zinc and Paroxetine. Med. J. Cairo Univ. 80( 2): 227-232, 2012 .

[44] M Joshi, M Akhtar, AK Najmi, AH Khuroo, D Goswami. Effect of zinc in animal models of anxiety, depression and psychosis Human Exp. Toxicol. 31(12 ):1237-43, 2012.

[45] J Samardzić, KSavić, N Stefanović, R Matunović, D Baltezarević, M Obradović, J Jancić, D Oprić, D Obradović. Anxiolytic and antidepressant effect of zinc on rats and its impact on general behavioural parameters. Vojnosanit Pregl. 70(4):391-5, 2013.

[46] IT Uzbay, CJ Wallis, H Lal, MJ Forster. Effects of NMDA receptor blockers on cocaine-stimulated locomotor activity in mice. Behav Brain Res. 108(1):57-61, 2000.

[47] T Hanania, NR Zahniser. Locomotor activity induced by noncompetitive NMDA receptor antagonists versus dopamine transporter inhibitors: opposite strain differences in inbred long-sleep and short-sleep mice. Alcohol Clin Exp Res. 26(4):431-40, 2002.

[48] S Bullock, E Manias, A Galbraith. Fundamentals of Pharmacology. Pearson Education Australia, 5, 2007.

[49] TG Smart, AM Hosie, PS Miller. Zn2+ ions: modulators of excitatory and inhibitory synaptic activity. Neuroscientist. 10(5):432-42, 2004.

[50] MF O'Neill, G Shaw. Comparison of dopamine receptor antagonists on hyperlocomotion induced by cocaine, amphetamine, MK-801 and the dopamine D1 agonist C-APB in mice. Psychopharmacol. (Berl).145(3):237-50, 1999.

[51] KC Berridge, JW Aldridge. Super-stereotypy I: enhancement of a complex movement sequence by systemic dopamine D1 agonists. Synapse 37,194-204, 2000.

[52] J Komorowska, SM Pellis. Regulatory mechanisms underlying novelty-induced grooming in the Laboratory rat, Behav. Process. 67(2), 287-93, 2004.

[53] HM Barros, SL Tannhauser, MA Tannhauser, M Tannhauser. The Effects of GABAergic drugs on grooming behaviour in the Open field," Pharmacol. Toxicol. 74 (4-5), $339-44,1994$

[54] $\mathrm{H} \mathrm{Xu}$, HJ Yang, GM Rose. Chronic haloperidol-induced spatial memory deficits accompany the upregulation of $\mathrm{D}(1)$ and $\mathrm{D}(2)$ receptors in the caudate putamen of $\mathrm{C} 57 \mathrm{BL} / 6$ mouse. Life Sci. 91(9-10):322-8, 2012.

[55] DD Mott, R Dingledine. Unraveling the role of zinc in memory. PNAS. 108(8), 3103-3104, 2011.

[56] F Khakpai, M Nasehi, A Haeri-Rohani, A Eidi, MR Zarrindast. Scopolamine induced memory impairment; Possible involvement of NMDA receptor mechanisms of dorsal hippocampus and/or septum. Behav. Brain Res. 231(1):1-10, 2012.

[57] A Degroot, MB Parent. Increasing acetylcholine levels in the hippocampus or entorhinal cortex reverses the impairing effects of septal GABA receptor activation on spontaneous alternation. Learn. Mem. 7:293-302, 2000.

[58] AJ Russo. Decreased Zinc and Increased Copper in Individuals with Anxiety. Nutr Metab Insights. 2011; 4: 15, 2011.

[59] M Pytliak, V Vargova, V Mechirova. Serotonin receptors: From molecular biology to clinical applications. Physiol Res. 60(1):15-25, 2011.

[60] AW Goddard, SG Ball, J Martinez. Current perspectives of the roles of the central norepinephrine system in anxiety and depression. Depress Anxiety. 27(4):339-350, 2010. 